\title{
Multipositional and transnational members of the Hungarian economic elite at the end of the 1990s: Their social characteristics and income chances*
}

\author{
György Lengyel**
}

Based on empirical research, the paper investigates two segments of the Hungarian economic elite: multipositionals - who hold three or more positions - and the leaders of transnational companies. It investigates the social characteristics and income chances of the two groups; income chances are measured in relative terms. Multipositionality was more frequent among leaders of private than state-owned companies, and less typical among managers of foreign than Hungarian companies. Multipositionals had two and a half, transnationals more than three times better income chances than the rest of the economic elite. Regression models revealed that besides multipositionality and foreign ownership, middle class social origin and a continuous career also had a positive effect on income chances.

Die empirische Studie stellt zwei Segmente der wirtschaftlichen Elite Ungarns vor: die multipositionale Elite, Unternehmensführer mit drei oder mehr Führungspositionen, und Manager transnationaler Unternehmen. Untersucht werden soziale Merkmale und Einkommenschancen der beiden Gruppen. Über Multipositionalität verfügen häufiger Leiter privatwirtschaftlicher als Leiter staatseigener Unternehmen, häufiger Manager ungarischer als Manager ausländischer Unternehmen. Bei den Einkommenschancen hingegen haben die Manager transnationler Unternehmen es besser: Sie verfügen dreimal größere, multipositionale Manager über eine zweieinhalb Mal größere Einkommenschance als der Rest der wirtschaftlichen Elite. Regressionsmodelle zeigen, dass - neben der Multipostionalität und ausländischem Anteilsbesitz - eine mittelständische Herkunft und ein kontinuierlicher Karriereverlauf einen positiven Effekt auf die Einkommenschancen haben.

Key words: economic elite, business leaders, managers, transnational companies, multipositionality, post-socialist transformation, Hungary, income differences

* Manuscript received: 18.01.08, accepted: 01.10 .08 (1 revision)

** György Lengyel, Prof. Dr., Institute of Sociology and Social Policy, Corvius University of Budapest. Main research areas: Emerging economic elites, entrepreneurs, unemployment and the social impacts of information technology. Corresponding address: gyorgy.lengyel@uni-corvinus.hu. 


\section{Introduction}

This article is based on an empirical research carried out in 1998 in Hungary among the members of the Hungarian economic elite. A more detailed conceptual and historical analysis of the topic can be found in the book which this paper is based on (Lengyel 2007). In that book, there was more scope to investigate the long and short term changes of the recruitment patterns of the Hungarian economic elite, and their relationship with the systemic changes, to compare the social and attitudinal characteristics of the economic elite and the rest of the population, and to describe the specificities of policy makers, bankers and managers. An overview of recent developments in the formation of postsocialist countries' economic elite can be found in an other volume (Lane et al. 2007). In this paper, I intend to focus on two sub-groups of the Hungarian economic elite: the multipositionals and the transnationals. There is much talk concerning both groups in public discourse, concerning their power, interests and social settings, and few empirically established investigations to be relied on. Therefore it might be useful to exploit survey evidence and to describe the specificities of those who cumulate economic positions and those who represent multinational corporations in a moment when systemic changes ended and when the consolidation of the reproduction processes of the capitalist market economy started.

Economic elite is meant to be those who are able, by their personal decisions, to significantly influence the reproduction processes of the national economy. Decision-making competence has been operationalized by top institutional positions. Therefore, along with the top leaders of the largest banks and enterprises, the top leaders of the economic policy makers were taken into account. The sample consisted of four segments. We interviewed 72 top leaders (above the level of head of department) of 3 economic ministries (industry, agriculture, finance), 58 members of 3 parliamentary committees (economy, agriculture, finance), 34 top leaders of 35 banks and 76 top leaders of the 100 largest companies according to turnover. In the banks and corporations, the positions of CEOs, deputy CEOs and presidents were taken into account during selection. Recent research has drawn attention to the distinction between elite and leadership (Higley-Pakulsi 2008). For our purposes in this paper, however, the two terms are interchangeable.

In the first chapter of this paper, we investigate the social characteristics of those who cumulate decision-making positions: the multipositionals. They may belong to the business elite or, alternatively, be part of the economic policy maker groups. The second chapter focuses on the business elite, investigating the social features of the leaders of transnational banks and enterprises. 


\section{The multipositional elite}

We count as part of the multipositional elite all those who hold roles in three or more directorial or supervisory boards at the same time. A typical scenario is for example if a person is in a CEO position and at the same time also sits on two supervisory boards. Another - less frequent, but existing - example is when a ministry delegates top officials into the board of a state-owned enterprise. Over a quarter $(27.1 \%)$ of the economic elite belongs to the multipositional elite. Apart from the firm for which the person was selected for the sample, the size of these firms was irrelevant. What counted was that the elite member took part in the supervision and control of the other companies. Researchers examining the theme of interlocking directorates are trying to see what firms are typically connected by the persons of the leaders (Useem 1978/1979; Vedres 2000). Findings showed that the interlocking directorates do not necessarily coincide with the interwoven ownership structures, and managerial overlap may have several different reasons (Scott 1990; Lengyel 1993; Tomka 1999). These questions however are not examined here in detail. We will investigate only whether the multipositional elite demonstrate social and cultural specificities as compared to the rest of the elite segments, and if they do, what are they?

Evidence shows that the multipositional elite differed from the rest of the economic elite in their organizational positions as well as in several aspects of their way of life. In recruitment, education and career patterns, however, they hardly deviated from the average of the economic elite. As for organizational affiliations, half the multipositional elite were from the enterprise, a quarter from the banking sector.

Table 1. Distribution of the multipositional and non-multipositional elite by segments $(1998, \%)$

\begin{tabular}{|l|c|c|c|c|c|}
\hline & ministry & parliament & Bank & company & $\mathrm{n}$ \\
\hline multipositional elite & 18.5 & 3.1 & 27.7 & 50.7 & 65 \\
\hline non-multipositional elite & 34.3 & 32.0 & 6.9 & 26.8 & 175 \\
\hline Cramer's V & \multicolumn{5}{|c|}{$.43 * * * *$} \\
\hline
\end{tabular}

$* * * * \mathrm{p}<.0001$

Multipositionality and intersegmental relations were extremely strong: threefifths of bankers and two-fifths of company managers accumulated leading positions. It is to be added that every sixth of the top ministry officials also belonged to this circle. The latter phenomenon can be ascribed to membership of the supervisory boards of state-run firms subordinated to the ministries.

On the whole, over two-fifths of the business elite belonged to the multipositional elite, while every tenth of the economic policy-makers did. Half of the leaders of private firms and a third of the managers of state-owned 
companied accumulated positions, and multipositionality better characterized Hungarian than foreign firms. The multipositional elite did not differ from the rest of the elite as regards former state socialist party membership, or education. The only special feature was that the holders of several diplomas were slightly overrepresented among them.

Some arguments claim that multipositionality in general is proportional with economic strength, and as such, it is an indicator of it (Useem 1978). It is rightfully presumed - the argument claims - that the more leading positions one possesses, the greater influence one has on economic decisions of key importance. There are some cases when this correlation is only tangentially and tendentially asserted, e.g. in the case of involvement in the management staff of unsuccessful companies belonging to the sphere of interest of an institution. Although this emergency presence does manifest a combination of managerial posts and multipositionality, it in fact indicates the weakness and not strength of at least one of the economic units and therefore the difficulties of the whole economic network it belongs to (Lengyel 1993/2007). Another phenomenon is participation in the control of less significant small firms, or the involvement in the management of family enterprises. The latter might have a positive impact on the household income, but since in most cases the firms concerned are small, involvement in them means extra work which might restrict participation in economic decisions of nationwide importance.

Considerably more multipositional elite members than the average of the economic elite reported that their actual income was more than what was deemed necessary. Their per capita household income was the double of that of the unipositional elite members. Both the multipositional elite member and his family members had shares in other firms and received premiums to a larger than average degree.

Table 2. Net monthly income from main position, annual premium, and per capita net household income of the multipositional and non-multipositional elite as compared to the average of the elite $(1998, \%)$

\begin{tabular}{|l|c|c|c|c|}
\hline & $\begin{array}{c}\text { net monthly } \\
\text { income }\end{array}$ & annual premium & $\begin{array}{c}\text { per capita net } \\
\text { household income }\end{array}$ & $\mathrm{n}$ \\
\hline multipositional elite & 175.1 & 195.5 & 166.1 & 55 \\
\hline non-multipositional elite & 72.3 & 64.5 & 75.2 & 149 \\
\hline total & 100.0 & 100.0 & 100.0 & 204 \\
\hline Eta & $.26^{* * *}$ & $.18^{* * *}$ & $.20^{* * *}$ & \\
\hline$* * * \mathrm{p}<.001$
\end{tabular}

In the multipositional elite, housing mobility was more strongly tied to getting to managerial or elite positions, while among the unipositional elite those who continued to live in the same home as before becoming leader were overrepresented. Every eighth member of the multipositional elite as against 
every third of the unipositional elite lived in the countryside. This is related to the fact that among MPs, who mostly lived outside the capital, multipositionality was rare because of the rules of incompatibility. As for housing, the multipositional elite had a significantly more favourable situation in terms of both housing size and number of rooms. They more often employed domestics, went on holidays, and ensured their children's elite education.

Table 3. Some indicators of the way of life in the multipositional and non-multipositional elite (1998, \%)

\begin{tabular}{|l|c|c|c|c|c|}
\hline & $\begin{array}{c}\text { children learn } \\
\text { abroad or attend } \\
\text { foreign school at } \\
\text { home }\end{array}$ & $\begin{array}{c}\text { children learn } \\
\text { tennis, sailing, } \\
\text { riding }\end{array}$ & $\begin{array}{c}\text { has regular } \\
\text { or occasional } \\
\text { domestic }\end{array}$ & $\begin{array}{c}\text { collects } \\
\text { paintings, art } \\
\text { works }\end{array}$ & $\mathrm{n}$ \\
\hline $\begin{array}{l}\text { multipositional } \\
\text { elite }\end{array}$ & 47.7 & 60.0 & 56.9 & 46.2 & 65 \\
\hline non-multip. elite & 32.0 & 32.1 & 27.4 & 27.4 & 175 \\
\hline Cramer's V & $.15^{*}$ & $.25^{* * * *}$ & $.28^{* * * *}$ & $.18^{* * *}$ & \\
\hline
\end{tabular}

$* \mathrm{p}<.05, * * \mathrm{p}<.01, * * * \mathrm{p}<.001, * * * \mathrm{p}<.0001$

Far more of the multipositional than the average of the economic elite opined that the individual could best protect his own interests, instead of the institutions or the family. The multipositional elite was significantly more satisfied, and deemed the perspectives of their family more favourably than the average of the elite.

Table 4. Rate of the satisfied with different aspects of life within the multipositional and non-multipositional elite (1998, \%)

\begin{tabular}{|l|c|c|c|c|c|}
\hline & with life so far & $\begin{array}{c}\text { with future } \\
\text { prospects }\end{array}$ & $\begin{array}{c}\text { with standard } \\
\text { of living }\end{array}$ & with income & $\mathrm{n}$ \\
\hline multipositional elite & 100.0 & 78.5 & 90.8 & 86.2 & 65 \\
\hline $\begin{array}{l}\text { non-multipositional } \\
\text { elite }\end{array}$ & 85.1 & 58.3 & 72.6 & 65.1 & 175 \\
\hline Cramer's V & $.21 * * *$ & $.19 * * *$ & $.19^{* * *}$ & $.21 * * *$ & \\
\hline
\end{tabular}

$* * * \mathrm{p}<.001,{ }^{* * * *} \mathrm{p}<.0001$

That applies to the assessment of their personal and material aspects, because in their evaluation of the perspectives of the country there was no difference between the multipositional elite and the rest of the economic elite.

\section{The transnational elite}

About three-quarters of the largest companies in our sample of 1998 were partly or wholly - foreign owned, and there was no difference between companies and banks in this regard. The leaders of foreign-owned or Hungarian- 
owned companies also did not differ as to former state socialist party membership.

Divergences between the two groups were detected in qualifications: among the managers of foreign-owned companies, university graduates and economists were overrepresented as against legal graduates and other diploma holders among the managers of Hungarian firms. This might be partly explained by the relatively late professionalization of managerial jobs in Hungary.

As regards shareholding in the given firm, there was no significant difference between managers of foreign and Hungarian firms, but the family members of the managers of Hungarian firms held shares in other companies to a larger degree. Underlying this was the fact that among the spouses of the managers of Hungarian firms, leaders and self-employed persons were overrepresented while an above-average rate of the spouses of foreign company managers did not work. This might be partly due to the income differences and partly due to the differences concerning the scope and density of networks. Regarding best friends, foreign company leaders mainly made friends with other managers, while the leaders of Hungarian firms also had intellectuals and entrepreneurs as friends to an above-average degree. As regards the future material prospects of the population, the Hungarian company managers were less optimistic than their foreign counterparts. The two groups differed as to housing mobility patterns, too. Those who moved to their current residences after rising to their elite positions were overrepresented among the managers of foreign companies. That was obviously due to the fact that every fifth of the managers of foreign firms were foreigners. A quarter of the managers of Hungarian firms were and remained residents of the countryside.

As the late 1990s table statistics suggest, the managers of foreign and Hungarian firms differed less from each other than the managers of state-owned firms differed from private firm managers, principally because there were fewer variables along which their attitudes and opinions displayed significant differences. This rule does not apply to every age and every factor, since at the beginning of the decade the critical factor was foreign or Hungarian ownership. An analysis of advertisements for managerial posts at the beginning of the decade revealed that foreign firms were markedly different as regards selection criteria and in terms of offered incomes (Bartha et al. 1992). The latter aspect remained true until the end of the decade for both personal and household income: managers of partly or wholly foreign-owned firms earned significantly more than managers of Hungarian firms.

Per capita household income appears to be about three times the income of Hungarian company managers. This is still below the fourfold difference between businessmen and economic politicians, and far below the ten-to-one ratio of the economic elite and the active population, but it is more marked than 
the difference between the managers of state-owned and private firms, as well as between bankers and managers, the latter two differences not being significant.

Table 5. Income and premiums of managers of foreign and Hungarian firms as compared to the average of the business elite 1998 (\%)

\begin{tabular}{|l|c|c|c|c|}
\hline & net monthly income & annual premium & $\begin{array}{c}\text { per capita net } \\
\text { household income }\end{array}$ & $\mathrm{n}$ \\
\hline $\begin{array}{l}\text { Hungarian-owned } \\
\text { firm }\end{array}$ & 42.8 & 66.1 & 41.8 & 26 \\
\hline foreign-owned firm & 128.4 & 113.6 & 128.2 & 55 \\
\hline business elite & 100.0 & 100.0 & 100.0 & 81 \\
\hline Eta & $.29 * * *$ & $.09 \mathrm{~ns}$ & $.27^{* *}$ & \\
\hline
\end{tabular}

${ }^{*} \mathrm{p}<.05, * * \mathrm{p}<.01, * * * \mathrm{p}<.001, * * * * \mathrm{p}<.0001$

Somewhat more than a third of the examined firms were partly, and another third wholly foreign owned. Among banks wholly foreign-owned, while among companies partly foreign-owned companies were overrepresented. Going into more detail on this aspect, some further characteristics can be explored. It relates to sectoral distribution and different tertiary educational trends, that economists were overrepresented among the managers of wholly foreign firms as against technical, legal and other graduates in the management of partly or wholly Hungarian-owned companies. This coincides with our previous finding in this respect and at the same time refines it, because it sheds light on the professional background of mixed ownership.

Table 6. Qualifications of the manager by rate of foreign ownership (1998, \%)

\begin{tabular}{|l|c|c|c|c|}
\hline & technical & Economic & legal and other & $\mathrm{n}$ \\
\hline $\begin{array}{l}\text { wholly } \\
\text { Hungarian }\end{array}$ & 31.0 & 41.4 & 27.6 & 29 \\
\hline partly foreign & 38.5 & 59.0 & 2.6 & 39 \\
\hline wholly foreign & 17.9 & 74.4 & 7.7 & 39 \\
\hline Cramer's V & & \multicolumn{3}{|c|}{$.39^{* * *}$} \\
\hline
\end{tabular}

$* * * \mathrm{p}<.001$

There was no difference between the wholly foreign and the mixed foreign/Hungarian firms in terms of profitability, but the two groups differed in how they judged their possibilities of growth and perspectives.

As regard growth possibilities, less than a third of the Hungarian and partly foreign companies as against two thirds of wholly foreign enterprises increased their employment in the previous year. This could be important from the elite perspective because the success of the corporation is a sign and measure of the success of the leaders themselves. On average, nine-tenths of the company managers forecast success for the next three years. While nearly $100 \%$ of the managers of wholly foreign firms shared this conviction, only four-fifths of 
large Hungarian companies had similar hopes, and the managers of mixed ownership firms expressed opinions between the two. In terms of growth tendencies, the dividing line was thus between the wholly foreign firms and the rest. This is attributed to the foreign companies' greater investment requirement to enter the market, their larger capital strength and tax allowances.

Table 7. Indicators of a firms' success by rate of foreign ownership (1998, \%)

\begin{tabular}{|l|c|c|c|c|}
\hline & lucrative firm & $\begin{array}{c}\text { firm increased } \\
\text { employment last } \\
\text { year }\end{array}$ & $\begin{array}{c}\text { manager says firm } \\
\text { will be successful in } \\
\text { the next three years }\end{array}$ & $\mathrm{n}$ \\
\hline wholly Hungarian & 86.2 & 26.7 & 79.3 & 29 \\
\hline partly foreign & 87.5 & 30.0 & 89.7 & 40 \\
\hline wholly foreign & 87.5 & 67.5 & 97.4 & 40 \\
\hline Cramer's V & $\mathrm{ns}$ & $.38^{* * * *}$ & $.24 *$ & \\
\hline
\end{tabular}

${ }^{*} \mathrm{p}<.05, * * * * \mathrm{p}<.0001$

Over half of the managers of Hungarian and mixed ownership companies belonged to the multipositional elite (as members of three or more directorial or supervisory boards), this rate being one-third for the leaders of wholly foreign firms. In this regard again, the dividing line was between the managers of wholly foreign-owned firms and those of the Hungarian-owned and mixed proprietorship companies, multipositional managers being overrepresented among the latter. The Hungarian firms were obviously better embedded in the local institutional context and social networks. Their managers joined the strategic control and governance of other firms via cross-ownership and personal relations, and they had a better chance of having active capital in their families. One can't claim that foreign company leaders have smaller chances of accessing capital from their families. But most of the great transnational companies present in Hungary are not family firms, and their leaders report a significantly smaller proportion of family businesses in their background than do managers of native or mixed property corporations. While less than half the managers of fully foreign-owned firms had active capital personally or in their families, this rate was seven-eighths for the wholly Hungarian-owned firms and seven-tenths for the companies of mixed ownership.

A frequent feeling of exhaustion was characteristic of the business elite but loneliness was not, and there is no considerable change here if the criterion of foreign or Hungarian ownership is taken into account. When, however, it comes to the toleration of norm-breaching behaviour - which characterized over twofifths of the business elite on the average - one finds a substantial difference by ownership: more than half the managers of fully Hungarian-owned firms accepted this opinion, as against slightly over one-third of the managers of fully foreign-owned companies. 
Table 8. Indicators of anomy and alienation in the business elite by rate of foreign ownership (1998, \%)

\begin{tabular}{|l|c|c|c|c|}
\hline & $\begin{array}{c}\text { often feels tired, } \\
\text { exhausted }\end{array}$ & often feels lonely & $\begin{array}{c}\text { feels true that if one } \\
\text { wants to succeed, one } \\
\text { is forced to breach } \\
\text { certain rules }\end{array}$ & $\mathrm{n}$ \\
\hline $\begin{array}{l}\text { wholly } \\
\text { Hungarian }\end{array}$ & 43.3 & 3.3 & 56.7 & 30 \\
\hline partly foreign & 56.4 & 15.4 & 41.0 & 39 \\
\hline wholly foreign & 48.7 & 12.8 & 35.9 & 39 \\
\hline Cramer's V & $\mathrm{ns}$ & $\mathrm{ns}$ & $.26^{*}$ & \\
\hline
\end{tabular}

$* \mathrm{p}<.05$

The most marked difference in this regard was between the economic elite and the active population, in the sense that the elite tolerated norm breaching much less than the rest of the people. Now another feature is added: violation of norms was condemned by the managers of wholly foreign-owned companies more than by the average of the business elite. The fact that getting ahead by the infringement of certain rules was more tolerated by Hungarian leaders and especially by the population could be interpreted to a large extent as the heritage of the economic ideology and practice of the second economy (Gábor 1989). During the last period of state socialism "finding the small gates if the large one is closed" was seen as a virtue rather than a vice, or at least was not markedly understood as a sin in people's minds. Otherwise a government campaign against the "small gates" idea could not have so easily undermined the delicate and tacit agreement that held between the governed and the governing elites, as it has been shown it did (Kovách 2006). It was also partly attributable to entrepreneurial culture that in evaluating norm-evading behaviours the managers of wholly foreign-owned companies tolerated the violation of certain rules to a far lesser degree than the rest of the business elite, and this difference was similarly significant between foreigners and Hungarian managers.

The influence of foreign capital upon the Hungarian elite can be examined from this personal angle as well. One can measure the rate of foreigners among the business elite, and their specificities as compared to Hungarians. One-sixth of the business elite were foreign citizens, the majority working for wholly foreignowned forms, the minority (one-third) for firms of mixed ownership. The relatively low rate of foreigners means most fully foreign-owned companies were managed by Hungarians. The generally maintained view that in the late nineties wholly foreign-owned firms were directed by foreign managers in Hungary was not substantiated.

The nationality of the managers did not correlate with business segments, demographic factors or educational indices. Nor was nationality related to multipositionality or to whether the manager or his family had capital property 
or not. That means that it was not the person of the manager but the ownership of the firm that was decisive in differentiating according to the cultural and material resources of the elite. The foreign elite (i.e. managers of non-Hungarian nationality) had some peculiar traits as to social origin, way of life and attitudes. A considerably larger portion originated from middle-class families; the relevant way-of-life indicators revealed that they had better material conditions than the Hungarian managers although the number of dependents per household was higher and nearly half their spouses did not work. Foreigners deemed their prospects more favourable and complained of circumstances less than the members of the Hungarian elite. Their opinion of how to achieve one's interests was markedly different from the Hungarian business elite's. The Hungarian elite stressed hard work and the importance of personal contacts, while the foreigners trusted in the efficiency of the political system. The foreign elite members had a more balanced view of the role of the state versus the individual and family in protecting their interests than did the Hungarian business elite. Multipositionality was more typical of Hungarian businessmen as was membership of professional societies. As for the ratio of available and necessary income, most foreigners said their standing was above satisfactory level, while the corresponding rate was less than half among Hungarian businessmen.

Another question is how foreign ownership or nationality influenced incomes. At first we compared net personal income/month, annual bonus and per capita household income by the rate of foreign ownership of the companies, and then by the citizenship of the managers (foreign/Hungarian).

Table 9. Income rates of Hungarian and foreign business elite members (1998)

\begin{tabular}{|l|c|c|c|c|c|}
\hline & & $\begin{array}{c}\text { personal net } \\
\text { income/month } \\
(\%)\end{array}$ & $\begin{array}{c}\text { annual } \\
\text { premium } \\
(\%)\end{array}$ & $\begin{array}{c}\text { per capita } \\
\text { household } \\
\text { income (\%) }\end{array}$ & $\mathrm{n}$ \\
\hline $\begin{array}{l}\text { by ownership of } \\
\text { company }\end{array}$ & $\begin{array}{c}\text { wholly } \\
\text { Hungarian }\end{array}$ & 100.0 & 100.0 & 100.0 & 15 \\
\hline & partly foreign & 261.0 & 170.1 & 348.0 & 23 \\
\hline & wholly foreign & 350.1 & 122.8 & 258.7 & 23 \\
\hline & Eta & $31^{*}$ & $13 \mathrm{~ns}$ & $29 *$ & \\
\hline $\begin{array}{l}\text { by citizenship of } \\
\text { manager }\end{array}$ & Hungarian & 100.0 & 100.0 & 100.0 & 55 \\
\hline & foreign & 310.1 & 115.6 & 254.9 & 6 \\
\hline & Eta & $.39 * * *$ & $.03 \mathrm{~ns}$ & $.28^{* *}$ & \\
\hline
\end{tabular}

${ }^{*} \mathrm{p}<.05, * * \mathrm{p}<.01, * * * \mathrm{p}<.001$

As one can see, there is some justification for the foreign managers to be more satisfied with their income than the Hungarians. The differentiation is again between the - partly or wholly - foreign-owned company and those owned by Hungarians. As regards personal income, wholly foreign-owned firms offered nearly a quarter higher salaries than partly foreign-owned ones, but in regard to 
annual bonuses, the latter offered higher bonuses, though the margin was not significant. As for per capita income, managers of firms of mixed ownership had the greatest advantage.

Table 10. Models explaining the income of the business elite by nature of ownership and characteristics of the leader

\begin{tabular}{|c|c|c|}
\hline & $\begin{array}{l}\text { 1st model } \\
\text { Dependent variable: logarithm of } \\
\text { net personal income/month in the } \\
\text { business elite: } \ln (\mathrm{JOV}) \mathrm{B} \text { (Beta) }\end{array}$ & $\begin{array}{l}\text { 2nd model } \\
\text { Dependent variable: logarithm of } \\
\text { net personal income/month in the } \\
\text { business elite: } \ln (\mathrm{JOV}) \mathrm{B} \text { (Beta) }\end{array}$ \\
\hline $\begin{array}{l}\text { KULFTUL } \\
\text { foreign ownership }\end{array}$ & $\begin{array}{c}.34 \\
(.29) \\
\end{array}$ & $\begin{array}{c}.24 \\
(.21)\end{array}$ \\
\hline $\begin{array}{l}\text { SZEGM company } \\
\text { segment }\end{array}$ & $\begin{array}{l}-.63 \\
(-.31) \\
\end{array}$ & $\begin{array}{c}-.81 \\
(-.39) \\
\end{array}$ \\
\hline $\begin{array}{l}\text { KULF } \\
\text { foreign citizenship }\end{array}$ & $\begin{array}{c}.85 \\
(.29)\end{array}$ & $\begin{array}{c}.94 \\
(.32)\end{array}$ \\
\hline $\begin{array}{l}\text { MULTIPOZ } \\
\text { multipositionality }\end{array}$ & $\mathrm{ns}$ & ns \\
\hline $\begin{array}{l}\text { ALLTUL } \\
\text { state ownership }\end{array}$ & ns & ns \\
\hline $\begin{array}{l}\text { KARRUGR } \\
\text { career by leaps }\end{array}$ & - & $\begin{array}{l}-89 \\
(-29)\end{array}$ \\
\hline $\begin{array}{l}\text { VVOLTE } \\
\text { entrepreneur among } \\
\text { pa-rents/grandparents } \\
\end{array}$ & - & $\begin{array}{l}.35 \\
(.19)\end{array}$ \\
\hline $\begin{array}{l}\text { FFOKU } \\
\text { third-level education }\end{array}$ & - & ns \\
\hline $\begin{array}{l}\text { TUL } \\
\text { has personal or } \\
\text { family capital } \\
\text { property }\end{array}$ & - & ns \\
\hline $\begin{array}{l}\text { KOR } \\
\text { age }\end{array}$ & - & ns \\
\hline $\begin{array}{l}\text { MSZMP } \\
\text { state socialist party } \\
\text { membership }\end{array}$ & - & $\mathrm{ns}$ \\
\hline $\begin{array}{l}\text { HULLAM } \\
\text { had ebbs and tides } \\
\text { during career }\end{array}$ & - & ns \\
\hline $\begin{array}{l}\text { NEME } \\
\text { male }\end{array}$ & - & ns \\
\hline $\mathrm{n}$ & 79 & 78 \\
\hline constant & 5.74 & 8.57 \\
\hline corrected r square & .31 & .38 \\
\hline
\end{tabular}

Although readiness to answer dropped massively when it came to inquiry into incomes and the information gained must be handled with caution, similarly 
marked divergences were found between the Hungarian and foreign elite. The deviation in income was even greater for this criterion than for that of foreign or Hungarian ownership, while the deviation in annual premium was smaller. We tested with regression models the role of individual factors, the segment (industry or bank) foreign ownership, citizenship, multipositionality and state or private ownership in shaping the income of the business elite. Taking the natural logarithm of the net personal income/month for the dependent variable, the following results were achieved.

The regression analysis reveals that the effects of the segment, foreign ownership and foreign management are independent of each other in the explanatory model. After filtering out the cross-effects, their individual effects remained, meaning that foreign ownership and foreign citizenship entailed cumulative income advantages.

In the extended model, it was also examined to what extent the inner differentiation of elite incomes was attributable to the social and demographic factors that proved decisive in rising into the elite. Foreign managers working for foreign-owned firms and banks still enjoyed net income advantages, while most of the conditioning factors taken into account when examining the chances of entering the elite proved insignificant in the inner differentiation of the business elite by income.

None of the following factors played a role in explaining income differences: third-level education as a presumed indicator of expertise; former membership in the Hungarian Socialist Workers' Party; demographic features; state or family capital assets; or multipositionality. What seemed to be important according to the breakdowns proved to be insignificant in the model when the impact of the other variables were included. What influenced income chances in the model among the social background variables was the pattern of social mobility. Those whose parents/grandparents included entrepreneurs earned significantly more than the average of the business elite, as did those who had an uninterrupted career rise.

Admission to the economic elite was conditioned by several factors, among which education played a salient role, as well as former etatist party membership and gender (Lengyel 2007). Under identical institutional conditions, the income chances within the business elite were most strongly influenced by the degree of continuity of the mobility patterns. It enhanced one's chances of entering the economic elite that one have a disjunctive career with great leaps, but within the business elite a smooth career progression pattern had better chances of getting more income. As regards intergenerational mobility, those issuing from a middle-class family had better net income chances; as regards intragenerational mobility, also those stood better chances who rose continuously without digressions, leaps or relapses. 
A final question is which dimensions most influenced the efficiency indicators of a company. Using refined methods of network analysis, Balázs Vedres concluded that joint ventures outperformed other property forms, including foreign ownership in the second half of the 1990s (Vedres 2004). In our calculation, very few of the success indexes of a firm were related to the proprietorial conditions and even more rarely were they connected with the personal traits of the managers. Profit was more characteristic of firms whose leaders were multipositional. Growth in employment - which is the best indicator of a stable and prosperous situation under the given circumstancesmainly characterized private firms, first of all banks, and under similar conditions it was more typical of companies whose leaders came from middleclass or entrepreneurial families. As regards subjective assessment, banks and managers of firms in foreign ownership regarded their companies as more successful than the average. Our earlier results based on a panel survey indicated that there was a very strong correlation between the managers' early prognosis of success and the survival chances of the firms. It was proved true for a broader representative sample of manufacturing enterprises that the firms whose managers deemed their companies successful at the beginning of the 1990s survived to a greater rate than the rest (Janky-Lengyel 2004). Also, proportionately more of the firms that declared refraining from norm breaching as important survived. While the first factor suggests that subjective indicators may be the basis for a good prognosis, the second reveals that there is a positive correlation between abiding by the laws of the market and economic success.

\section{References}

Gábor, R.I. (1989): Second Economy in State Socialism: Past Experience and Future Prospects. The Case of Hungary, in: European Economic Review, 33, 509-604.

Higley, J.P. (2008): Elite and Leadership Change in Liberal Democracies, in: Masamischi, S.(ed.), Elites: New Comparative Perspectives, Leiden: Brill, 7-23.

Janky, B./Lengyel, G. (2004) Vállalati magatartás és túlélési esélyek a posztszocialista átmenetgazdaságban. (Enterprise behaviour and survival chances in a post-socialist transition economy), in: Közgazdasági Szemle, 6, 7, 699-716.

Kovách, I. (ed.) (2006): Társadalmi metszetek. (Social segments) Napvilág K. Budapest.

Lane, D./Lengyel, G./Tholen, J. (eds.) (2007): Restructuring of the Economic Elite after State Socialism, Stuttgart: Ibidem Verlag.

Lengyel, G. (1993): A multipozicionális gazdasági elit a két világháború között. (The Multipositional Economic Elite in the Interwar Period) Budapest: ELTE.

Lengyel, G. (2007): A magyar gazdasági elit társadalmi összetétele a 20. század végén. (The Social Composition of the Hungarian Economic Elite at the End of the $20^{\text {th }}$ Century), Budapest: Akadémiai K. 
Scott, J. (1990): Intercorporate Structure in Britain, the United States and Japan, in: Scott, J. (ed.): The Sociology of Elites. Critical Perspectives, Aldershot: E. Elgar Publ. Ltd., 2, 307-320.

Tomka, B. (1999): Érdek és érdektelenség. A bank-ipari viszony a századforduló Magyarországán, 1892-1913. (Concern and Unconcern: The Bank-Industry Relation at the Turn of the Century in Hungary, 1892-1913), Debrecen: MM.

Useem, M. (1978): The inner group of the American capitalist class, in: Social Problems, 25, 225-240.

Useem, M. (1979): The social organization of the American business elite and participation of corporation directors in the governance of American institutions, in: American Sociological Review, 44, 53-572.

Vedres, B. (2000): A tulajdonosi hálózatok felbomlása. A rekombináns tulajdonformák szerepe és a hazai nagyvállalatok tulajdonszerkezetének jellemzői a kilencvenes évek végén.(The dissolution of proprietory networks. The role of recombinant property forms and characteristics of the ownership structure of Hungarian great enterprises at the end of the nineties), in: Közgazdasági Szemle, XLVII, 9, 680-699.

Vedres, B. (2004): Testing narratives of post-socialism. Transition and sequence approaches to the ownership histories of the largest Hungarian corporations 1991-1999, in: Review of Sociology of the HAS, 10, 1, 24-46. 